
3 Research Square
Preprints are preliminary reports that have not undergone peer review.
They should not be considered conclusive, used to inform clinical practice, or referenced by the media as validated information.

\title{
The influence of chamotte on densification and mechanical properties of ceramic membranes made from Gabonese kaolin
}

\author{
Yannick Nongni Jiogho ( $\square$ njynongni@gmail.com ) \\ Joseph Marie Sieliechi \\ Universite de Ngaoundere \\ Sophie Cerneaux \\ University of Montpellier: Universite de Montpellier \\ Marc Cretin \\ University of Montpellier: Universite de Montpellier \\ Martin Benoît Ngassoum \\ Universite de Ngaoundere
}

Universite de Ngaoundere https://orcid.org/0000-0001-5343-5700

\section{Research Article}

Keywords: Gabonese kaolin, Chamotte, Microstructure, Porous ceramic, Mechanical Properties

Posted Date: March 1st, 2022

DOI: https://doi.org/10.21203/rs.3.rs-1345058/v1

License: (a) This work is licensed under a Creative Commons Attribution 4.0 International License. Read Full License 


\section{Abstract}

Porous ceramic membranes have been successfully prepared by roll pressing using low cost local raw materials. The porous ceramic membranes were obtained by sintering five ceramic paste formulations containing kaolin, rice husk and chamotte powders at a temperature range of $1100-1300^{\circ} \mathrm{C}$. The fired ceramic membranes were characterized by determining their porosity, pore size, flexural strength and microstructure. The porous ceramic produced had a pore volume ranging from $27.3 \pm 1.4$ to $58.5 \pm 0.5 \%$, an average pore diameter from $4.7 \pm 2.5$ to $14.5 \pm 1.3 \mu \mathrm{m}$ and a mechanical strength from $0.8 \pm 0.1$ to $10.0 \pm 0.6 \mathrm{MPa}$. The results show that the addition of chamotte increases the structural reorganization temperature of the composite, but does not affect the temperature range of densification and complete mullitization of the material. The random distribution of the inert phase (chamotte and quartz) induces a non-uniform behavior of the porosity, the average pore diameter and the mechanical strength after sintering of the samples. The characteristics of the porous materials obtained at $1300^{\circ} \mathrm{C}$ are adequate to be used in microfiltration.

\section{Introduction}

The development of mineral microfiltration (MF) membranes is often facing two major drawbacks that are the sintering temperature and the porosity, depending on the various mineralogy of clays and proportions of porogens used [1-3]. To optimize the control of porosity, degreasers like (sands, limestones, or chamottes) [4,5] and melting (alkali and alkaline earth rich phyllosilicates; feldspars or chalk) [6-9] can be used as additives. However, results whether on macroporous volume, mechanical strength or sintering temperature, vary from one author to another and these variations depend on the proportions of the raw material used and the sintering conditions applied to consolidate the membranes. The use of these additives leads to a microstructural heterogeneity in the porous ceramics directly related to the physicochemical and structural properties of the initial powders, to the particle size distribution of the raw materials as well as to the different transformations and interactions of the raw materials during the sintering process. In general, the initial formulations are chosen to meet the specifications of the desired final products. When using chamottes as degreasers in the presence of clay in the elaboration of porous ceramics, several parameters such as temperature, sintering time and formulation proportions are key parameters during the sintering process to have quality products [4]. Chamotte is a clay that is preliminarily pre-fired at a temperature above the equilibrium temperature of all chemical transformations $[10,4]$. To this effect, in the framework of a scientific partnership between Cameroon and Gabon devoted to the valorization of local materials, the valorization of a kaolin deposit appears of renewed interest in the production of microfiltration ceramic membranes with appropriate properties. The Bikougou clay deposit is a refractory kaolinite deposit whose exploitation by local population is to date limited to artisanal pottery. The main constituent of kaolin ores is kaolinite. The theoretical formula of pure kaolinite $\mathrm{Si}_{2} \mathrm{Al}_{2} \mathrm{O}_{5}(\mathrm{OH})_{4}$ is often presented as $\mathrm{Al}_{2} \mathrm{O}_{3} \cdot 2 \mathrm{SiO}_{2} \cdot 2 \mathrm{H}_{2} \mathrm{O}$ [11-13]. The most important of these properties is the formation of mullite occurring during the sintering of the raw membrane which gives the material a good mechanical strength [1-3]. The study undertaken in this paper aims to investigate the 
level of influence of the temperature and the proportions of chamotte on the structural and microstructural properties of ceramic membranes based on a refractory kaolinite from Gabon and rice husks used as porogen.

\section{Materials And Experimental Procedure}

\section{Materials and samples preparation}

The studied clay was collected from Bikougou, in the Northern region of Gabon, crushed and sieved at $200 \mu \mathrm{m}(\mathrm{d} 50=8.4 \mu \mathrm{m})$ and the final bulk composition was determined by Inductively Coupled Plasma Mass Spectrometry (ICP-MS) to be $62.5 \mathrm{wt} \%$ of $\mathrm{SiO}_{2}, 7.6 \mathrm{wt} \%$ of $\mathrm{Al}_{2} \mathrm{O}_{3}, 0.5 \mathrm{wt} \%$ of $\mathrm{Fe}_{2} \mathrm{O}_{3}, 2.3 \mathrm{wt} \%$ of $\mathrm{K}_{2} \mathrm{O}, 0.1 \mathrm{wt} \%$ of $\mathrm{Na}_{2} \mathrm{O}$ and $0.2 \mathrm{wt} \%$ of $\mathrm{MgO}$. Clay was used as crude raw clay and also after firing at $1300^{\circ} \mathrm{C}$ to form chamotte. Chamotte agglomerates were crushed and sieved at controlled size of $200 \mu \mathrm{m}$ (d50 $=66.5 \mu \mathrm{m}$ ). as The major chemical constituents of the chamotte are: $57.2 \mathrm{wt} \%$ of $\mathrm{SiO}_{2}, 8.5 \mathrm{wt} \%$ of $\mathrm{Al}_{2} \mathrm{O}_{3}, 0.6 \mathrm{wt} \%$ of $\mathrm{Fe}_{2} \mathrm{O}_{3}, 2.2 \mathrm{wt} \%$ of $\mathrm{K}_{2} \mathrm{O}, 0.1 \mathrm{wt} \%$ of $\mathrm{Na}_{2} \mathrm{O}$ and $0.2 \mathrm{wt} \%$ of $\mathrm{MgO}$. Rice husks that are organic wastes from rice cultivation collected from Yagoua, in the Farnorth, Cameroon were used as porogen agent, crushed and sieved at controlled size of $100 \mu \mathrm{m}(\mathrm{d} 50=12.8 \mu \mathrm{m})$. Its final bulk composition is 27.8 wt \% of $\mathrm{SiO}_{2}, 1.6$ wt \% of $\mathrm{Al}_{2} \mathrm{O}_{3}, 1.0$ wt\% of $\mathrm{Fe}_{2} \mathrm{O}_{3}, 1.0 \mathrm{wt} \%$ of $\mathrm{K}_{2} \mathrm{O}, 0.1 \mathrm{wt} \%$ of $\mathrm{Na}_{2} \mathrm{O}$, $1.1 \mathrm{wt} \%$ of $\mathrm{CaO}, 0.1 \mathrm{wt} \%$ of $\mathrm{SO}_{3}, 0.5 \mathrm{wt} \%$ of $\mathrm{P}_{2} \mathrm{O}_{5}$ and $0.3 \mathrm{wt} \%$ of $\mathrm{MgO}$ (Table 1 ). The formulation used for the preparation of the materials are summarized in Table 2.

Table 1 Chemical and mineralogical compositions of the raw materials (Values are given at $\pm 0.1 \mathrm{wt}$. $\%)$. 


\begin{tabular}{llll} 
Element & Raw clay & Chamotte & Rice husks \\
\hline $\mathrm{SiO}_{2}$ & 62.5 & 57.3 & 27.8 \\
\hline $\mathrm{Al}_{2} \mathrm{O}_{3}$ & 7.6 & 8.5 & 1.6 \\
\hline $\mathrm{K}_{2} \mathrm{O}$ & 2.3 & 2.2 & 1.0 \\
\hline $\mathrm{Fe}_{2} \mathrm{O}_{3}$ & 0.5 & 0.6 & 1.0 \\
\hline $\mathrm{CaO}$ & 0.1 & $/$ & 1.1 \\
\hline $\mathrm{SO}_{3}$ & 0.1 & $/$ & 0.1 \\
\hline $\mathrm{MgO}$ & 0.2 & 0.2 & 0.3 \\
\hline $\mathrm{Na}_{2} \mathrm{O}$ & 0.1 & 0.1 & 0.2 \\
\hline $\mathrm{P}_{2} \mathrm{O}_{5}$ & $/$ & $/$ & 0.5 \\
\hline $\mathrm{LOI}^{(a)}$ & 4.6 & 0.5 & 61.6 \\
\hline $\mathrm{Crys}$ & Kaolalline phases $;$ quartz; Illite & Mullite; Quartz; Cristobalite &
\end{tabular}

aLOI: loss on ignition

\section{Methods}

The process flow diagram for the production of porous ceramic membrane is presented in Fig. 1. The specimens were prepared by adding different amounts of chamotte powder to the basic porous membrane mixture (clay and rice husk). Flat green bodies were prepared by roll pressing of a ceramic paste composed of the raw powders in the proportions presented in Table 2. For each heat treatment cycle, the temperature was increased at a rate of $2{ }^{\circ} \mathrm{C} / \mathrm{min}$ from Room Temperature (RT) to $500{ }^{\circ} \mathrm{C}$ with a dwelling step of $2 \mathrm{~h}$ to allow elimination of the pore former and organic additives present in the paste, then the temperature was increased to the final temperature (Tf) at $5{ }^{\circ} \mathrm{C} / \mathrm{min}$ and kept constant for $2 \mathrm{~h}$. The temperature was finally decreased at a rate of $10^{\circ} \mathrm{C} / \mathrm{min}$ to ambient temperature.

Table 2 Formulation of five ceramic membranes and sintering temperatures applied 


\begin{tabular}{lllll} 
Reference & Clay (wt \%) & $\begin{array}{l}\text { Rice husk } \\
(\text { wt } \%)\end{array}$ & $\begin{array}{l}\text { Chamotte } \\
(\text { wt \%) }\end{array}$ & Sintering Temperature $\left({ }^{\circ} \mathrm{C}\right)$ \\
\hline C0 & 80 & 20 & 0 & $1100 ; 1200 ; 1300$ \\
\hline C1 & 70 & 20 & 10 & $1100 ; 1200 ; 1300$ \\
\hline C2 & 60 & 20 & 20 & $1100 ; 1200 ; 1300$ \\
\hline C3 & 70 & 10 & 20 & $1100 ; 1200 ; 1300$ \\
\hline C4 & 60 & 10 & 30 & $1100 ; 1200 ; 1300$
\end{tabular}

The mineralogical compositions of the obtained porous ceramics membranes were analyzed by $\mathrm{X}$-ray diffraction (XRD). XRD analyses were carried out by means of a powder diffractometer "XRD Shimadzu1800 " using the Cu Ka1 radiation $(\lambda=0.15406 \mathrm{~nm})$. XRD experiments were achieved in step scan mode from $10^{\circ}$ to $35^{\circ}(2 \theta)$. Standard thermal analyses of the relevant powdered sample were realized using a "TGA-DTA 2960 TA Instrument" apparatus, operating under a constant dry air flow at a heating rate of 10 ${ }^{\circ} \mathrm{C} /$ min between room temperature and $1200^{\circ} \mathrm{C}$. Previously fired alumina was used as the reference material for all experiments. The porosity and pore size of fired samples were measured by $\mathrm{Hg}$ porosimetry (Micromeritics, AutoPore IV 9500). The flexural strength of the sintered samples was measured by the three-point bending method (universal LLOYD Instruments, LRX apparatus) using a span length of $30 \mathrm{~mm}$ and a cross-head speed of $10 \mathrm{~mm} \cdot \mathrm{min}^{-1}$. All experiments were carried out on a series of at least 5 supports to report an average strength for each series, following International Standard (IS) specifications. The microstructure of the fired samples was analyzed by Scanning Electron Microscopy (SEM) (Jeol-JSM5500). Fragments from the samples subjected to the mechanical test were collected, mounted on aluminum sample-holder and gold coated before the analysis.

\section{Results And Discussion}

\section{Phase evolution of the sintered samples}

Fig. 2 shows the variation of the XRD patterns of the sintered disks C0, C1 and C2 at temperatures of $1200^{\circ} \mathrm{C}$ (Fig. 2a) and $1300^{\circ} \mathrm{C}$ (Fig. 2b). At $1200^{\circ} \mathrm{C}$, the powdered ceramic disks show for both samples $\mathrm{C} 1$ and $\mathrm{C} 2$ mullite cores. Slow formation of this mullite phase occurred at this temperature of $1200^{\circ} \mathrm{C}$. It is hypothesized that nucleation of secondary mullite may occur in the residual primary mullite fraction, generated during the transformation of metakaolinite at $1035^{\circ} \mathrm{C}$ and the decomposition of chamotte at a temperature superior than (or above) $1100^{\circ} \mathrm{C}$ as indicated by the exothermic and endothermic DTA peaks (Fig. 3). These mullite cores then grow during further heat treatment. The nucleation and crystallization mechanism may be responsible for the formation of mullite in the second stage. By increasing the temperature to $1300^{\circ} \mathrm{C}$, a significant increase in the intensity of mullite peaks is observed compared to those sintered at $1200^{\circ} \mathrm{C}$. At 1200 and $1300^{\circ} \mathrm{C}$, cristobalite crystallization is also observed. The mullite 
nuclei contained in the amorphous matrix at $1200^{\circ} \mathrm{C}$ are derived from the transformation of metakaolinite. This essentially cubic mullite (primary mullite) is transformed into orthorhombic mullite up

to $1200^{\circ} \mathrm{C}$ according to (1) [14]:

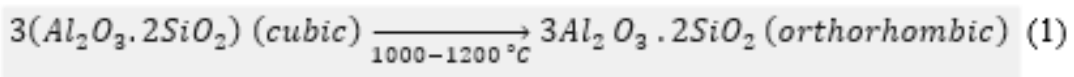

Compared to sample $\mathrm{C} 0$, this orthorhombic mullite phase is more noticeable in the samples $\mathrm{C} 1$ and $\mathrm{C} 2$ containing chamotte. The transformation of spinel into mullite can be polymorphic because the chemical composition of the two minerals is similar and they only differ by their crystallographic structure. With the decomposition of chamotte, a new type of mullite is formed. It is generally described as equiaxial mullite [15-19]. Finally, the reactive silica resulting from the transformation of metakaolinite and chamotte reacts with alumina to form secondary mullite.

\section{Thermal behavior}

Fig. 3 shows the thermal evolution of the $\mathrm{C} 2$ mixture and the raw clay. Compared to the thermal behavior of the Bikougou kaolinite and rice husk [3], we can see that the addition of chamotte powder brings great changes. The exothermic peaks of lignin and cellulose oxidation observed respectively in the range of 281 and $387^{\circ} \mathrm{C}$ and that of 387 and $450^{\circ} \mathrm{C}$ for the rice husk sample [2] were shifted from $318^{\circ} \mathrm{C}$ to 311 ${ }^{\circ} \mathrm{C}$ and from $430{ }^{\circ} \mathrm{C}$ to $418{ }^{\circ} \mathrm{C}$, respectively. The endothermic peak at $452{ }^{\circ} \mathrm{C}$ related to the dehydroxylation of clay and the formation of amorphous metakaolinite in the Bikougou kaolinite was shifted to a lower temperature and is masked by the high amplitude peaks of lignin and cellulose oxidation. In addition, the endothermic peak characteristic of the a-quartz to $\beta$-quartz transition has been shifted from $575{ }^{\circ} \mathrm{C}$ to 574 ${ }^{\circ} \mathrm{C}$ in the $\mathrm{C} 2$ mixture. Between $1022-1035^{\circ} \mathrm{C}$, we observe the appearance of a peak of very low amplitude that reflects a very slow heat change, which does not allow us to distinguish whether this thermal accident is an exo or endothermic phenomenon. This phenomenon is accompanied by a weight loss of $0.9 \%$ which characterizes the structural reorganization of the metakaolinite according to scheme (2) [19].

\section{$2\left(\mathrm{Al}_{2} \mathrm{O}_{3} \cdot 2 \mathrm{SiO}_{2}\right)($ metakaolinite $) \rightarrow \mathrm{Si}_{3} \mathrm{Al}_{4} \mathrm{O}_{12}(\mathrm{Al}-\mathrm{Si}-$ Spinel $)+\mathrm{SiO}_{2}$ (amorphous) (2)}

The initial stabilization of the structure of the chamotte material favors the diffusional reorganization of the metakaolinite [19]. As a result, around $1035^{\circ} \mathrm{C}$, only a slow coarsening mechanism remains. There is probably a phenomenon that triggers the shift of the exothermic peak of the Bikougou kaolinite from 947 ${ }^{\circ} \mathrm{C}$ to $1035^{\circ} \mathrm{C}$ in the $\mathrm{C} 2$ mixture. This may be related to the Al-O-Si lattice arrangement of the metakaolinite since the exothermic effect is shifted when the chamotte, which is a stable material, is added. The apparent activation energy related to the structural reorganization of metakaolinite represents the diffusion energy of $\mathrm{Al}^{3+}$ ions in loosely organized alumino-silicate structures, as it is the case for metakaolinite. This energy for the $\mathrm{C} 2$ mixture is of the same order of magnitude $(7 . \pm 1 \mathrm{j} / \mathrm{g})$ as that of the Bikougou kaolinite $(8 \pm 1 \mathrm{j} / \mathrm{g})$. This energy is equivalent to the breaking of Al-O bonds that initiates the structural reorganization of metakaolinite $[20,21]$. Between $1106-1200^{\circ} \mathrm{C}$, an endothermic peak is observed without any weight loss which characterizes the crystallization of mullite and the densification 
of the $\mathrm{C} 2$ mixture. Compared to the Bikougou kaolinite, the mullitization and densification peak shifted from $1133^{\circ} \mathrm{C}$ to $1137^{\circ} \mathrm{C}$. The apparent activation energy related to the mullitization and densification of the material is 11 times higher for the $\mathrm{C} 2$ mixture $(97 \mathrm{j} / \mathrm{g})$ than for the Bikougou kaolinite $(8 \mathrm{j} / \mathrm{g})$. We can therefore conclude that the chamotte delays the mullitization of the membranes during sintering.

\section{Average pore diameter, porosity and mechanical properties}

Fig. 4-6 show the evolution of pore size (Dmp), pore volume $(\mathrm{Vp})$ and mechanical strength $(\mathrm{Rm})$ of the membranes as a function of chamotte proportions at different sintering temperatures of 1100,1200 and $1300^{\circ} \mathrm{C}$.

It can be seen from Fig. 4 that the Dmp increases with an increasing temperature, ranging from 5.8 and $14.5 \mu \mathrm{m}$. At $1100^{\circ} \mathrm{C}$, the chamotte presence does not influence the Dmp if standard deviations are taken into account. For temperatures of $1200^{\circ} \mathrm{C}$ and $1300{ }^{\circ} \mathrm{C}$, the Dmp of $\mathrm{C} 1$ decreases by $31.5 \%$ and $21.4 \%$ respectively compared to $\mathrm{CO}$. On the other hand, when the chamotte percentage is increased to $20 \mathrm{wt} \%$ (C2 formulation), the Dmp decreases by $15.5 \%$ at $1200{ }^{\circ} \mathrm{C}$ and increases by $6.4 \%$ at $1300{ }^{\circ} \mathrm{C}$ compared to $\mathrm{CO}$.

From Fig. 5, the influence of three variables namely chamotte content, rice husk content and firing temperature on the pore volume $(\mathrm{Vp})$ of the sintered samples can be noticed. It can be seen that for a rice husk content of $20 \mathrm{wt} \%$, the $\mathrm{Vp}$ decreases with the temperature increase for $\mathrm{C} 1$ and increases for $\mathrm{C} 2$. For the $20 \mathrm{wt} \%$ rice husk content, it is found that at $1100^{\circ} \mathrm{C}$, the chamotte decreases the Vp compared to $\mathrm{C} 0$. Above $1100^{\circ} \mathrm{C}$, the chamotte increases the $\mathrm{Vp}$ of the membranes. For example, at $1200^{\circ} \mathrm{C}$, we have an increment of $18 \%$ and $10.4 \%$ of $\mathrm{CO}$ for $\mathrm{C} 1$ and $\mathrm{C} 2$, respectively. Finally, at $1300{ }^{\circ} \mathrm{C}$, there is an increment of $1.1 \%$ and $12.1 \%$ by volume of $\mathrm{C} 0$ for $\mathrm{C} 1$ and $\mathrm{C} 2$, respectively. For a rice husk proportion of $10 \mathrm{wt} \%$, we notice that the $\mathrm{Vp}$ decreases with increasing temperature for samples $\mathrm{C} 3$ and $\mathrm{C} 4$, but increases with chamotte contents. In the initial mixtures, the matrix phase of plastic clay and rice husk, added to the chamotte during a wet mixing process, causes discontinuities in the stacking of the clay plates, which promotes additional porosity. The chamotte being an amorphous material, the relative orientation of its particles in the membrane will influence the densification of the membrane. In general, the compacted clay particles are preferentially oriented tangentially to the non-plastic particles (chamotte and quartz) $[22,23]$. During firing, this preferential stacking between the matrix phase (clay + rice husk) and the chamotte will lead to trapped porosity. This trapped porosity will be favored by the competition between the granular growth and the densification of the membrane during sintering. The monotonic variation of the pore volume for low proportions of rice husk (C3 and C4) supports this hypothesis since the low rice husk content promotes more compact packing during the forming process, which in turn promotes densification during sintering. The same trend was observed by Moon and Lee [24]. As the chamotte content increases, densification is reduced, but the characteristic peak positions of the densification phenomenon occur at similar temperature ranges to those of the Bikougou kaolinite (Fig. 3).

It can be seen from Fig. 6 that the mechanical strength $(\mathrm{Rm})$ increases with the increase of both the sintering temperature and the chamotte proportions. That is to say an increment of $30 \%$ and $24 \%$ for $\mathrm{C} 1$ 
$(3.2 \pm 0.2 \mathrm{MPa})$ and $\mathrm{C} 2(3.1 \pm 0.6 \mathrm{MPa})$, respectively compared to $\mathrm{C} 0(2.50 \pm 0.03 \mathrm{MPa})$ at $1300{ }^{\circ} \mathrm{C}$. For rice husk contents of $20 \mathrm{wt} \%, \mathrm{Rm}$ is less than $4 \mathrm{MPa}$ and its variation with chamotte content and temperature (Fig.6) are monotonic. When the proportion of rice husk is reduced by $10 \mathrm{wt} \%$ in the matrix phase, the Rm increases exponentially at $1300^{\circ} \mathrm{C}$ with respect to $\mathrm{C} 0$. As an example, samples $\mathrm{C} 3$ and $\mathrm{C} 4$ have an additional increment of $302 \%(10 \pm 1 \mathrm{MPa})$ and $247 \%(9 \pm 1 \mathrm{MPa})$, respectively. This observation can be explained by the fact that the porogen content has been reduced and consequently generates a reduction of the pores playing the role of macroscopic defects that weaken the ceramic structure, and cause the reduction of the open porosity of the material. This ceramic will consolidate by densification and will become more and more rigid. Thus the $\mathrm{Rm}$ is inversely proportional to the porosity.

\section{Microstructure of the sintered samples}

The microstructure of $\mathrm{C} 0, \mathrm{C} 1, \mathrm{C} 2, \mathrm{C} 3$ and $\mathrm{C} 4$ samples sintered at $1300^{\circ} \mathrm{C}$ are presented in Fig. $7(\mathrm{a}-\mathrm{e})$, respectively. The SEM images evidence the heterogeneous character of the microstructure. Within the fine grain matrix phase, we observe very large grains of quartz in $\mathrm{C} 0$ and chamotte and quartz in $\mathrm{C} 1, \mathrm{C} 2, \mathrm{C} 3$ and $\mathrm{C} 4$. The micrographs are reflecting the evolution of the microstructure of chamotte membranes with increasing chamotte content. In the C3 and C4 samples, large quartz grains cannot be easily distinguished from chamotte grains but observations using optical microscopy revealed their homogeneous distribution. In the matrix phase, entrapped pores cannot be distinguished due to their small size in comparison to the used scale. However, few sintering defects are detected in all materials, and the presence of such defects is observed in all compacts whatever the chamotte content. Defects are large size elongated pores along the biggest grains whose existence is supposed to be favored by the differential densification during sintering between chamotte and matrix (Fig. 7b and 7c). Besides, differential dilatations of large quartz grains during cooling induce elongated cracks along grain boundaries. It is evidenced that all elongated pores and interfacial cracks lead to the lowering of the mechanical properties.

\section{Conclusion}

Refractory kaolinites mixed with kaolinitic chamotte of large grain size $(\leq 200 \mu \mathrm{m})$, are refractory mixtures that produce materials with heterogeneous microstructure in the temperature range of $1100-1300^{\circ} \mathrm{C}$. The use of silicated lignocellulosic materials as porogen agents in the development of porous materials in these mixtures increases the thermal refractivity of the material. The addition of chamotte increases the structural reorganization temperature of the composite, but does not change the temperature range of densification and complete mullitization of the material compared to that of the matrix phase (Bikougou kaolinite + rice husk). The consolidation and densification of the sintered materials are influenced by the thermal behavior of the matrix phase and the chamotte content. The quartz grains formed in the matrix phase during sintering and the chamotte are inert during the densification of the sintered samples. The random distribution of the inert phase (chamotte and quartz) induces a non-uniform behavior of the porosity, the average pore diameter and the mechanical strength after sintering of the C0, C1, C2, C3 and $\mathrm{C} 4$ samples. This random distribution of the inert phase leads to additional porosity and mechanical 
strength. The use of chamotte favors the formation of cracks and pore elongation due to the expansion of quartz aggregates or chamotte particles during the cooling process. Nevertheless, the characteristics of porous materials such as $\mathrm{Vp}, \mathrm{Dmp}$ and $\mathrm{Rm}$ obtained at $1300^{\circ} \mathrm{C}$ are sufficient to be used in microfiltration. As a perspective, it would be interesting to add a melting material to reduce the sintering temperature and improve the characteristics of the membranes.

\section{Declarations}

\section{Conflicts of interest}

The authors declare no conflicts of interest.

\section{Acknowledgement}

The authors would like to thank the financial support of The Erasmus Mundus Action 2 KITE Partnership, lot 18 ACP (2013-2617) and the support of the staff of the IEM (Institut Européen des Membranes) of University of Montpellier and the staff of the ENSAI (National School of Agro-Industrial Sciences) of University of Ngaoundere Cameroon.

\section{References}

[1] Hou, Z., Cui, B., Liu, L., Liu, Q. : Effect of the different additives on the fabrication of porous kaolinbased mullite ceramics. Ceram. Int. 2016, 42, 17254-

17258. https://doi.org/10.1016/j.ceramint.2016.08.020

[2] Abdullayev, A., Bekheet, M., Hanaor, D., Gurlo, A. : Materials and Applications for Low-Cost Ceramic Membranes. Membranes 2019, 9, 105. https://doi.org/10.3390/membranes 9090105

[3] Belibi Belibi, P., Nguemtchouin, M., Rivallin, M., Ndi Nsami, J., Sieliechi, J., et al. : Microfiltration ceramic membranes from local Cameroonian clay applicable to water treatment. Ceramics International, Elsevier, 2015, 41 (2), pp.2752 - 2759. https://doi.org/10.1016/j.ceramint.2014.10.090

[4] Djangang, C.N., Elimbi, A., Melo, U.C., Lecomte, G.L., Nkoumbou, C., Soro, J., et al. : Sintering of clay-chamotte ceramic composites for refractory bricks. Applied Clay Science 2008; 39: 1018. https://doi.org/10.1016/j.ceramint.2007.02.012

[5] Alima, M., Hadda, R., Sihem, B., Afef, A., Yasmina, T., Sabrina, L., et al.: Effect of chamotte on the structural and microstructural characteristics of mullite elaborated via reaction sintering of Algerian kaolin. J. mater Res.Technol 2019; 8(5):4010-4018. https://doi.org/10.1016/j.jmrt.2019.07.009

[6] Deutou, N.J.G., Beda, T., Biesuz, M., Boubakar, L., Melo, U.C, Kamseu, E., Sglavo, V.M.: Design and characterization of porous mullite based semi-vitrified ceramics. Ceramics International 2018. 
https://doi.org/10.1016/j.ceramint.2018.01.232_

[7] Lima., R.C.O., Lira, H.L., Neves, G.A., Silva, M.C., França, K.B.: Study of the influence of granite residue in different Compositions to prepare ceramic membranes. Materials Science Forum 2014; 798799: pp 542-547. https://doi.org/10.4028/www.scientific.net/MSF.798-799.542

[8] Souza, A.E., Teixeira, S.R., Santos, G.T.A., Longo, E.: Addition of sedimentary rock to kaolinitic clays: influence on sintering process. Cerâmica 2013; 59: 147-155. https://doi.org/10.1590/S036669132013000100017

[9] Monash, P., Pugazhenthi, G.: Development of ceramic supports derived from low-cost raw materials for membrane applications and its optimization based on sintering temperature. Int.J. Appl. Ceram. Technol 2011; 8(1) : 227-238. https://doi.org/10.1111/j.1744-7402.2009.02443.x_

[10] Kamseu, E., Bakop, T., Djangang, C., Melo, U.C., Hanuskova, M., Leonelli, C.: Porcelain stoneware with pegmatite and nepheline syenite solid solutions: pore size distribution and descriptive microstructure, J. Eur. Ceram. Soc 2013; 33 : 27752784. https://doi.org/10.1016/j.jeurceramsoc.2013.03.028

[11] Kolli, M., Hamidouche, M., Fantozzi, G., Chevalier, J. : Elaboration and characterization of a refractory based on Algerian kaolin, Ceram Int 2007; 33(8): 1435-1443.

https://doi.org/10.1016/j.ceramint.2006.06.009

[12] Kong, L.B., Chen, Y.Z., Zhang, T.S., Boey, J., Ma, F., Huang, H.: Effect of alkaline-earth oxides on phase formation and morphology development of mullite ceramics, Ceram. Int 2004; $30: 1319-1323$.

https://doi.org/10.1016/j.ceramint.2003.12.019

[13] Hajjaji, M., Kacim, S., Boulmane, M.: Mineralogy and firing characteristics of the clay from the valley of Ourika (Marocco). Applied Clay Science 2002. 21, p. 203-212. https://doi.org/10.1016/S01691317(01)00101-6

[14] Zhoua, H.M., Qiao, X.C., Yu, J.G. : Influences of quartz and muscovite on the formation of mullite from kaolinite. Applied Clay Sci. 2013. 80-81 : 176-181. https://doi.org/10.1016/j.clay.2013.04.004

[15] Ganesh, I., Ferreira, J.M.F.: Influence of raw material type and of the overall chemical composition on phase formation and sintered microstructure of mullite aggregates. Ceram Int. 2009; 35:2007-15.

https://doi.org/10.1016/j.ceramint.2008.11.008

[16] Comeforo, J.E., Fischer, R.B., Bradley, W.F. : Mullitization of kaolinite. J Am Ceram Soc. 1948;31(9):254-9. https://doi.org/10.1111/j.1151-2916.1948.tb14310.x 
[17] Djangang, C.N., Tchamba, A.B., Kamseu, E., Melo, U.C., Elimbi, A., Ferrari, A.M., Leonelli, C. :

Reaction sintering and microstructural evolution in metakaolin-metastable alumina composites. $J$ Therm Anal Calorim. 2014;117(3):1035-45. https://doi.org/10.1007/s10973-014-3937-6

[18] Chakraborty, A.K. : Phase transformation of kaolinite clay. Berlin:Springer 2014. p. 339. https://doi.org/10.1007/978-81-322-1154-9

[19] Sainz, M.A., Serrano, F.J., Bastida, J., Caballero, A. : Microstructural evolution and growth of crystallite size of mullite during thermal decompostion of kyanite. J Eur Ceram Soc. 1997;17:127784. https://doi.org/10.1016/S0955-2219(96)00231-2

[20] Mazzucato, E., Artioli, G., Gualtieri, A.: High temperature dehydroxylation of muscovite-2M 1: a kinetic study by in situ XRPD. Phys Chem Minerals. 1999 ; 26 (5) : 375-381.

https://doi.org/10.1007/s002690050197

[21] Prodanovi, D., Ivkovi, B., Radosavljevi, S.: Kinetics of the dehydroxylation and mullitization process of the halloysite from the farbani potok locality, Serbia. Applied Clay Sci. 1997 ; 12: 267-274.

https://doi.org/10.1016/S0169-1317(97)00011-2

[22] Agbarakwe, U.B., Babda, J.S., Masser, P.J.: Non-uniformities and pores formation, Mater. Sci. Eng. 1989; 109: 9-16.https://doi.org/10.1016/0921-5093(89)90559-5

[23] Shui, A., Zeng, L., Uematsu, K.: Relationship between sintering shrinkage anisotropy and particle orientation for alumina powder compacts, Scripta Mater 2006; 55 (9) : 831-834.

https://doi.org/10.1016/j.scriptamat.2006.07.026

[24] Moon, I.H., Lee, J.K.: Relation between sinterability and initial packing density in loosely sintered copper sphere compacts, Powder Metall 1987; 30 (4): 249254. https://doi.org/10.1179/pom.1987.30.4.249

\section{Figures}




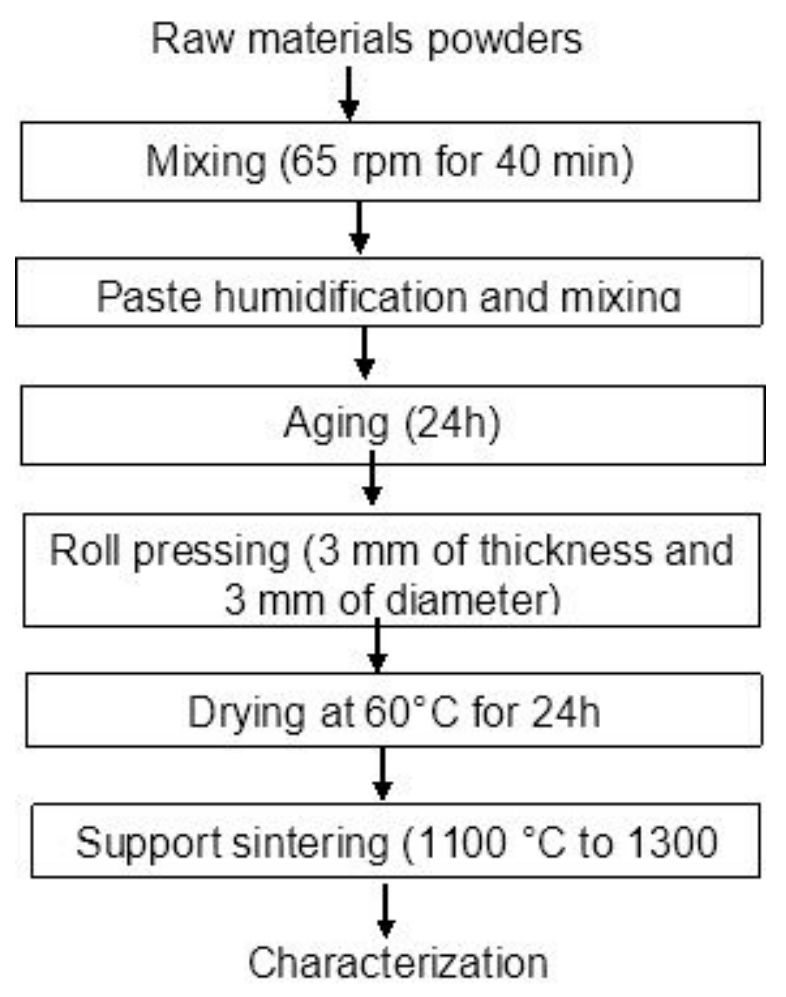

Figure 1

Process-flow diagram for production of the porous ceramic disks



Figure 2

XRD of sintered membrane disks at: (a) $1200^{\circ} \mathrm{C}$ and (b) $1300{ }^{\circ} \mathrm{C}$ for samples containing 0 wt $\%, 10 \mathrm{wt} \%$ and $20 \mathrm{wt} \%$ of chamotte for $\mathrm{C} 0, \mathrm{C} 1$ and $\mathrm{C} 2$, respectively. M - Mullite, Q - Quartz, C - Cristobalite, F - Feldspar 

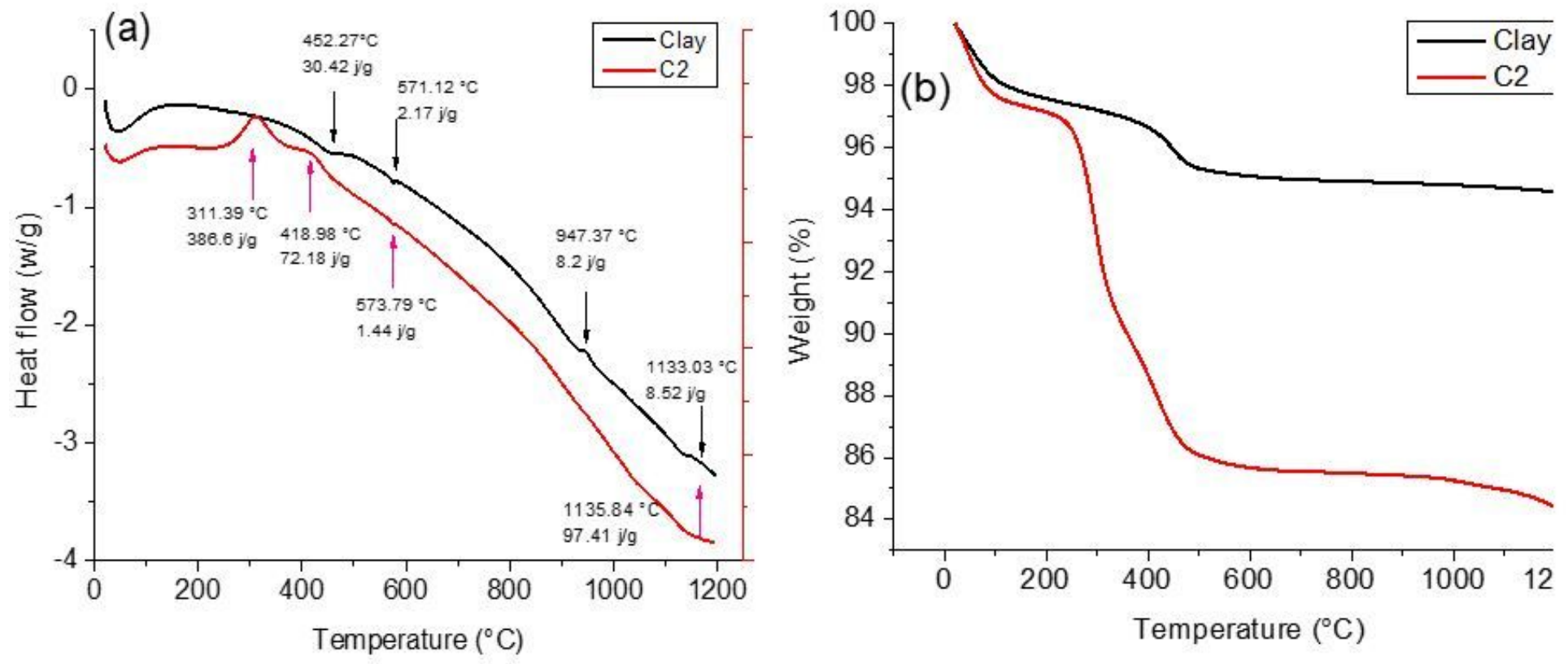

Figure 3

(a) Differential Thermal analysis and (b) Thermal Gravimetric curves of the clay material and C2 formulation

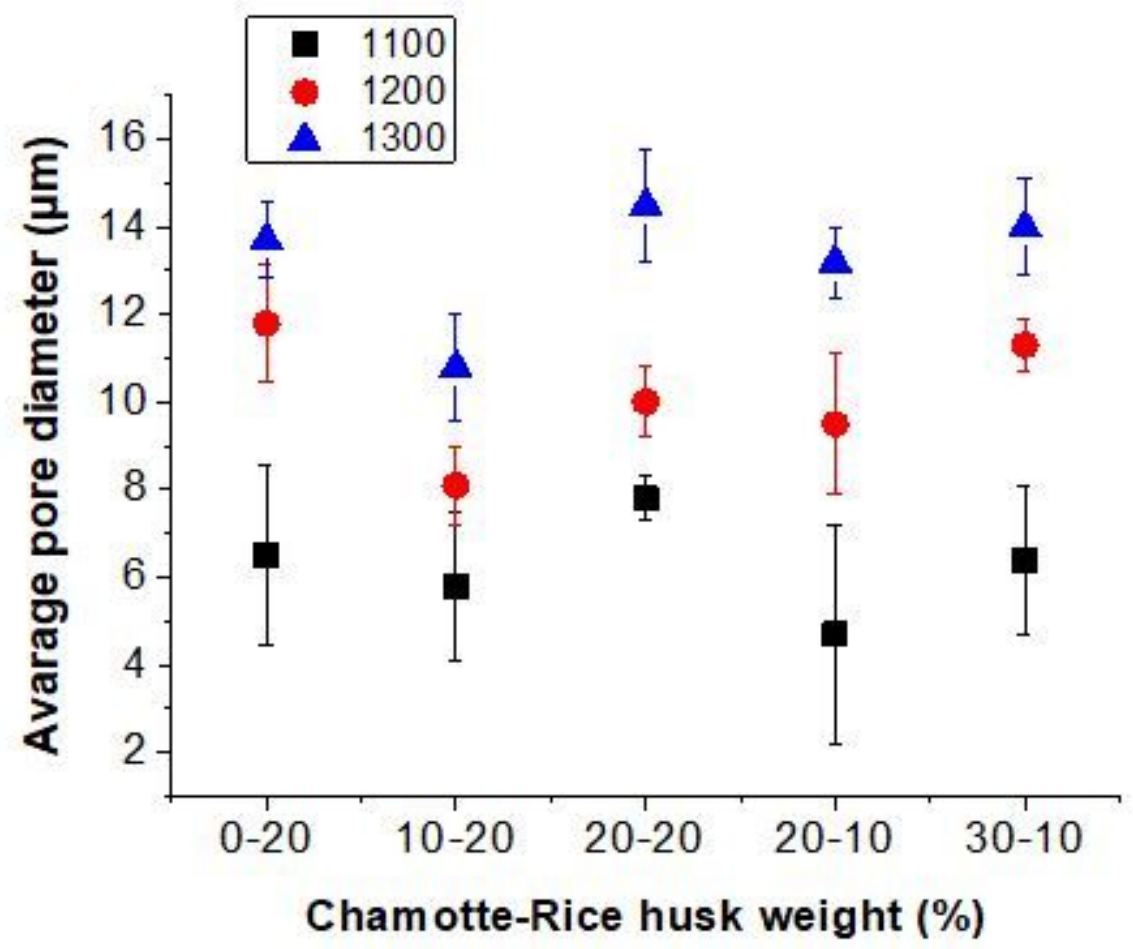

Figure 4 


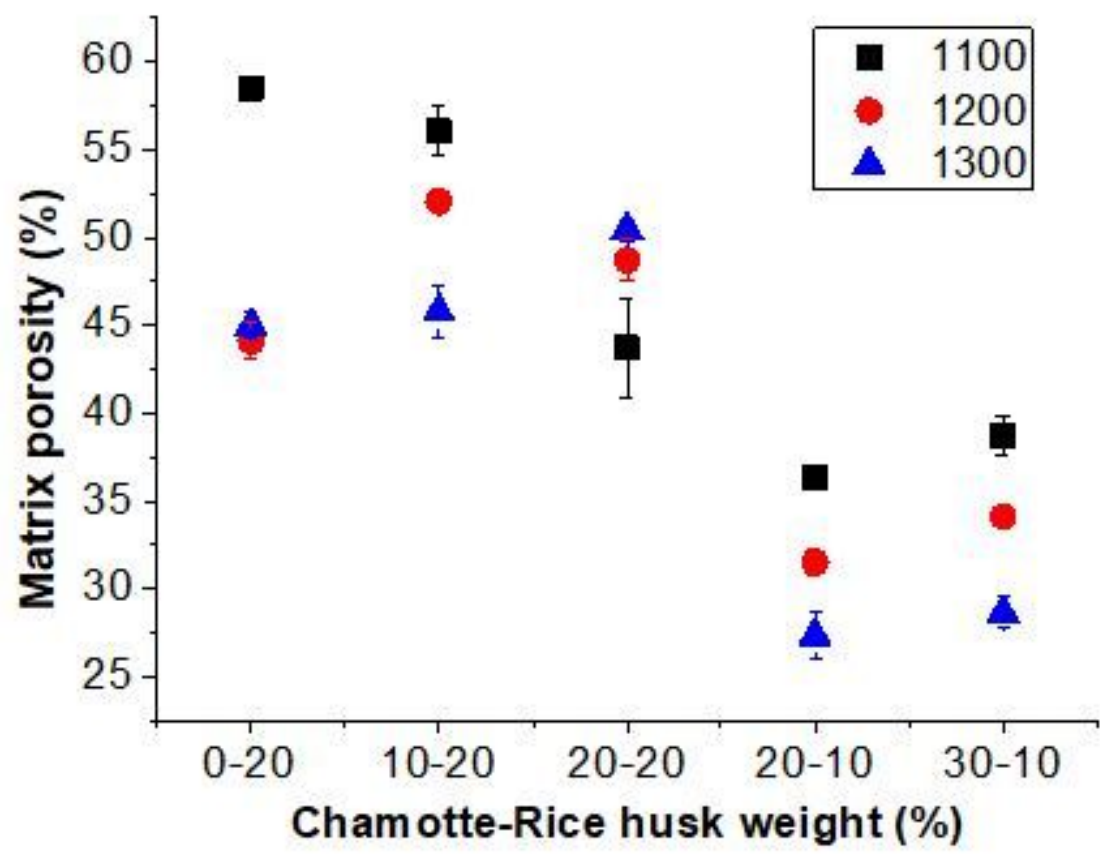

Figure 5

Matrix porosity at different firing temperatures as a function of chamotte quantity with rice husk

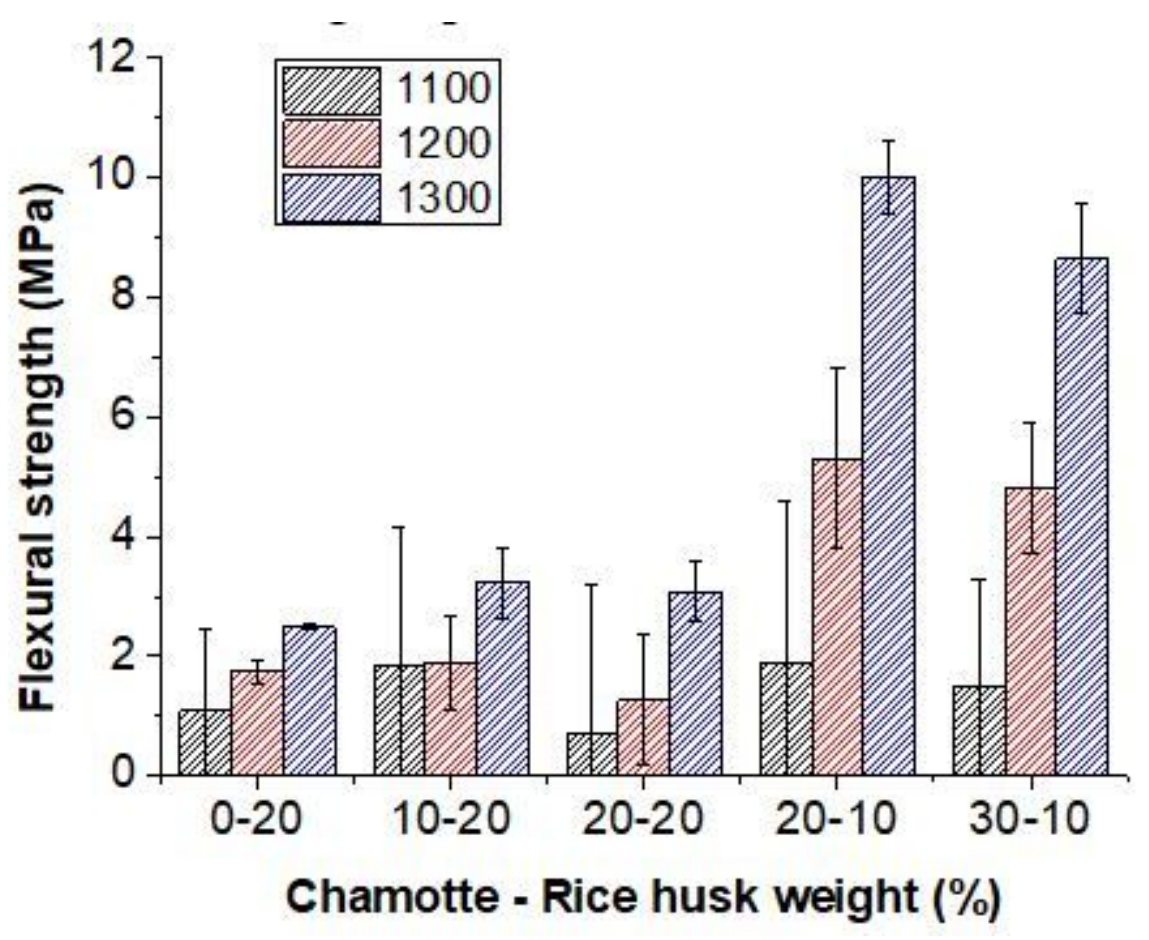

Figure 6 


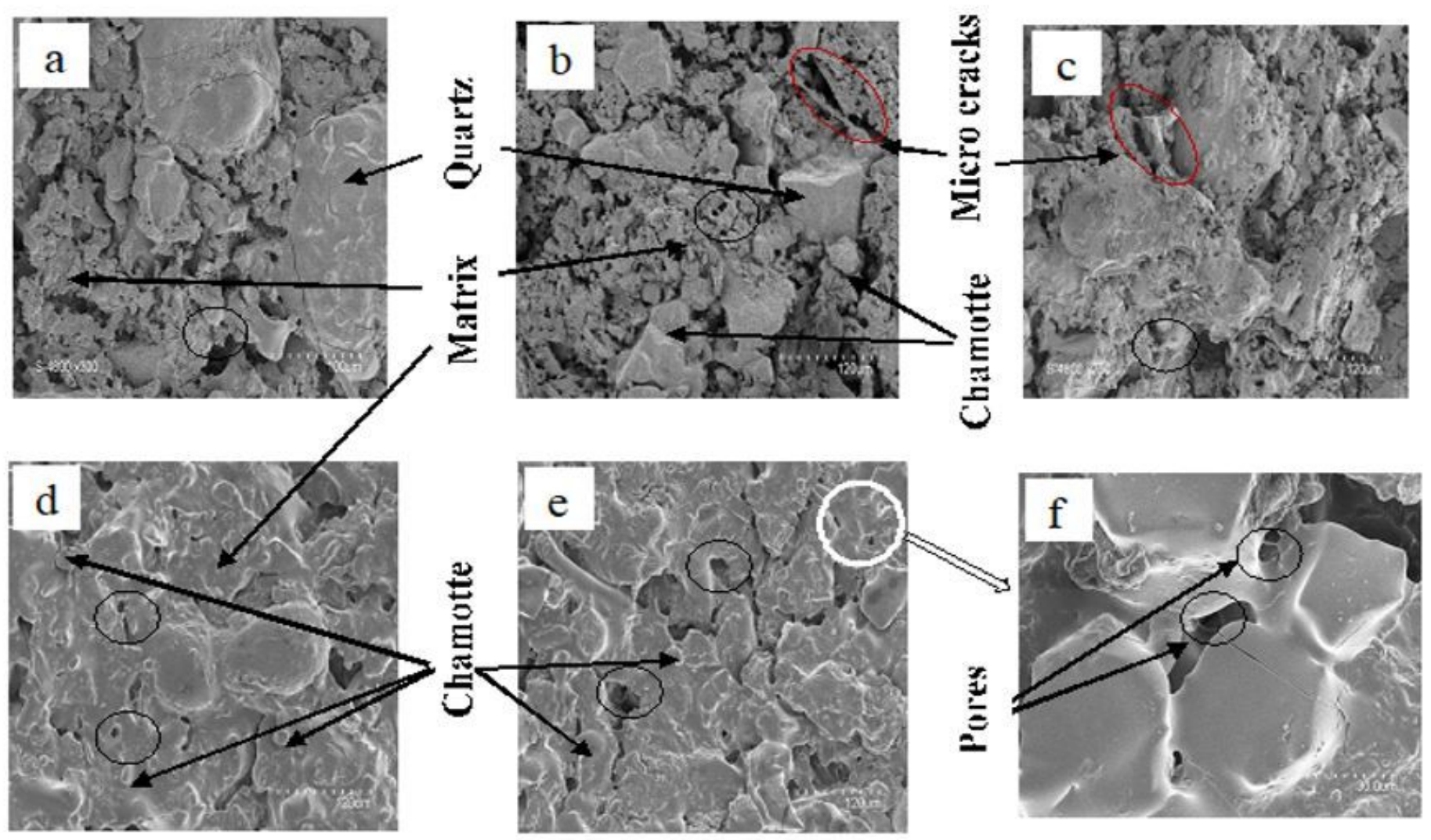

\section{Figure 7}

Microstructure observed by SEM of membranes fired at $1300^{\circ} \mathrm{C}$ : (a) C0; (b) C1; (c) C2; (d) C3 and (e) C4. (f) represents another magnification of image (e) 